\title{
BIOEKOLOGI BINTANG LAUT (ASTEROIDEA) DI PERAIRAN PULAU MENJANGAN KECIL, KEPULAUAN KARIMUNJAWA
}

\author{
Oleh \\ Desy Andaru Setyowati, Supriharyono*), Wiwiet Teguh Taufani \\ Program Studi Manajemen Sumberdaya Perairan \\ Departemen Sumberdaya Akuatik Fakultas Perikanan dan Ilmu Kelautan, Universitas Diponegoro \\ Prof. Sudharto, SH, Tembalang, Semarang, Jawa Tengah - 50275, Telp/Fax. +6224 7474698 \\ Email : andharoe27@,gmail.com
}

\begin{abstract}
ABSTRAK
Kepulauan Karimunjawa secara geografis, terletak di sebelah Barat Laut Kota Jepara. Kawasan Taman Nasional Laut Karimunjawa memiliki fungsi utama yaitu sebagai kawasan konservasi. Sebagian besar penduduknya bermata pencaharian sebagai nelayan. Perairan Pulau Menjangan Kecil memiliki banyak biota laut salah satunya yaitu Bintang Laut (Asteroidea). Pentingnya mempelajari Bintang Laut ini yaitu bahwa Bintang Laut memiliki fungsi sebagai pembersih serasah detritus di zona intertidal. Tujuan dari penelitian ini adalah untuk mengetahui kondisi terumbu karang, sebaran Bintang Laut, letak kedalaman Bintang Laut dan hubungannya. Penelitian ini dilakukan pada bulan November 2016 dan bulan Mei 2017. Materi dari objek penelitian ini adalah data persentase tutupan terumbu karang dan sebaran Bintang Laut yang terletak pada sisi barat dan sisi timur Pulau Menjangan Kecil. Metode yang digunakan dalam penelitian ini adalah metode deskriptif. Teknik sampling yang digunakan yaitu Random Sampling. Hasil pengukuran parameter fisika-kimia yang didapat pada penelitian ini yaitu normal. Hasil persentase tutupan terumbu karang masih dalam kondisi yang cukup baik. Hasil dan kesimpulan dari penelitian ini Bintang Laut yang ditemukan yaitu Linckia laevigata pada kedalaman 100-450 cm dengan kisaran diameter 20-30 cm, Nordoa tuberculata pada kedalaman 50-150 cm dengan kisaran diameter 1-20 cm dan Culcita novaeguinae pada kedalaman 100-200 cm dengan kisaran diameter 20-25 cm. Letak sebaran bintang laut yaitu berada pada karang hidup, karang mati, pecahan karang, substrat pasir dan lamun. Hubungan sebaran Bintang Laut dengan kedalaman yaitu dipengaruhi oleh faktor makanan. Adapun kondisi perairan di Pulau Menjangan Kecil saat malam hari yaitu banyak biota laut yang muncul menampakkan diri seperti ikan hiu, ular laut, ikan buntal, dan zooplankton yang dapat mengeluarkan cahaya berwarna biru.
\end{abstract}

Kata Kunci: Echinodermata, Sebaran Bintang Laut, Terumbu Karang, Pulau Menjangan Kecil, Karimunjawa.

\section{ABSTRACT}

Karimunjawa Islands, located in north west of Jepara. Taman Nasional Karimunjawa region has a main function for conservation area. Most of the population are fishermen. The waters of Menjangan Kecil Island have many marine biota, one of them is starfish (Asteroidea). So important for studying about starfish, because it has function for detritus litter in the intertidal zone. The purpose of this research is to identify starfish distribution, vertically, relationships of them and condition of coral reefs and they relationships. The research was do in November 2016 and May 2017. Materials of this research are percentage of coral reef covers, and the distribution of starfishon the east and west sides of Menjangan kecil island. This research uses descriptive method. Random sampling were used in this study. The comparison of physical-chemical parameters in this research on temperature and depth data are slightly different. The percentage in coral reef is in good condition. The result of starfish is founded Linckia laevigata in depth 100-450 cm with diameter 20-30 cm, Nordoa tuberculata in depth 50-150 cm with diameter $1-20 \mathrm{~cm}$ and Culcita novaeguinae in depth 100-200 cm with diameter 20-25 cm. The location of starfishs are on living coral, dead coral, fractions of coral, sands, and seagrass. The relation beetween the distribution of starfishs and the deeps is influented by food habit factor. As for the condition of Menjangan Kecil Island on night so many nocturnal biota such as shark, sea snake, fish, and zooplankton wich can glows blue light.

Keywords: Echinodermata, Starfish Distribution, Coral Reef, Menjangan Kecil Island, Karimunjawa. *) Penulis Penanggungjawab

\section{PENDAHULUAN}

Kepulauan Karimunjawa ditunjuk sebagai taman nasional dengan luas wilayahnya sekitar $111.625 \mathrm{Ha}$, terdiri dari luas daratan 7.033 Ha dan luas perairan 104.592 Ha. Kawasan Taman Nasional Laut Karimunjawa memiliki fungsi utama yaitu sebagai kawasan konservasi oleh karena itu tidak semua daerah di Karimunjawa dapat dimanfaatkan ataupun diolah bagi kepentingan manusia. Namun, sebagian besar penduduknya yang terkonsentrasi di Pulau Karimun bermata pencaharian sebagai nelayan (74,9 \%) (Dinas Perikanan dan Kelautan Jateng, 2003 dalam Aryati et al., 2007) 
Kepulauan Karimunjawa memiliki 27. Dari 27 pulau, 5 diantaranya merupakan pulau yang berpenghuni yakni Pulau Karimunjawa itu sendiri, Pulau Kemujan (kampung Suku Bugis), Pulau Nyamuk, Pulau Parang dan Pulau Genting. Pulau Menjangan Kecil memiliki pemandangan bawah laut yang indah, terdapat pula banyak biota laut yang menghuni di ekosistem karangnya, baik karang hidup maupun karang mati, salah satunya yaitu filum Echinodermata. Filum ini sering di temukan pada zona intertidal. Zona intertidal merupakan daerah laut yang dipengaruhi oleh daratan. Zona ini memiliki faktor fisik maupun faktor kimia yang mendukung semua organisme di dalamnya untuk dapat tumbuh dan berkembang dengan baik. Zona intertidal adalah daerah pantai yang terletak antara pasang tinggi dan surut terendah, daerah ini mewakili peralihan dari kondisi lautan ke kondisi daratan. Zona ini luasnya sangat terbatas, tetapi banyak terdapat variasi faktor lingkungan yang terbesar dibandingkan dengan daerah lautan lainnya. Karena itu keragaman organismenya sangat besar. Salah satu hewan yang terdapat di zona intertidal adalah hewan yang termasuk dalam filum Echinodermata (Nybakken, 1988 dalam Katili, 2011).

Bintang laut tidak memiliki nilai ekonomis, karena menurut masyarakat Pulau Karimunjawa sendiri bintang laut tidak memiliki nilai ekonomis untuk dimakan dan diperjual-belikan seperti filum Echinodemata lainnya yaitu teripang dan bulu babi. Namun, secara ekologis, bintang laut memiliki fungsi sebagai pembersih serasah detritus di zona intetidal. Keberadaan dari bintang laut sendiri yaitu sebagai hewan yang berasosiasi dengan terumbu karang, pembersih pantai dari material organik sehingga merupakan salah satu bioindikator laut yang masih bersih. Bintang laut (Asteroidea) memegang peranan penting dalam lingkungan pantai, yakni memakan bangkai dan cangkang-cangkang mollusca yang mengotori pantai, sehingga bintang laut dikenal sebagai hewan pembersih laut. Keberadaan bintang laut saat ini dipengaruhi oleh aktifitas manusia seperti pembuatan dermaga pada beberapa pulau dan perburuan bintang laut (Supono, 2012)

Tujuan dari penelitian ini adalah untuk mengetahui persentase kondisi terumbu karang, sebaran bintang laut secara vertikal, letak kedalaman bintang laut secara horizontal, dan hubungan sebaran bintang laut dengan letak kedalamannya.

\section{MATERI DAN METODE}

\section{Materi}

Materi dari objek penelitian ini adalah data persentase tutupan terumbu karang dan sebaran bintang laut yang terletak pada dua lokasi, yaitu sisi barat dan sisi timur, serta parameter lingkungan yang meliputi faktor fisika-kimia perairan di Pulau Menjangan Kecil, Karimunjawa. Peralatan yang digunaan dalam penelitian ini yaitu GPS (Global Positioning System) untuk menentukan koordinat lokasi penelitian, roll meter untuk mengukur persentase tutupan terumbu karang, secchi disc modification untuk mengukur kedalaman serta kecerahan perairan, kuadran transek dengan ketelitian $1 \times 1 \mathrm{~m}^{2}$ untuk menghitung individu bintang laut, thermometer untuk mengukur suhu perairan, refraktometer untuk menukur salinitas perairan, $\mathrm{pH}$ paper untuk mengukur $\mathrm{pH}$ perairan, kamera underwater untuk mendokumentasikan gambar didalam air, dan set skin dive untuk membantu proses menyelam didalam air.

\section{Metode Penelitian}

Metode yang digunakan dalam penelitian ini adalah metode deskriptif. Menurut Travens dalam Umar (2001), penelitian yang menggunakan metode deskriptif adalah penelitian yang dilakukan untuk mengetahui nilai variabel mandiri, baik satu variabel atau lebih (independent) tanpa membuat perbandingan menghubungkan dengan variabel lain. Hal serupa kemudian dikemukakan oleh Sugiyono (2003), metode penelitian deskriptif merupakan penelitian yang bertujuan untuk memberikan gambaran dari variable penelitian.

\section{Teknik Sampling}

Teknik sampling yang digunakan dalam penelitian ini ada dua metode yaitu metode Random Sampling. . Metode Random Sampling sudah sangat banyak digunakan dalam penelitian termasuk dalam penelitian skripsi, metode ini dilakukan menentukan 2 stasiun pengamatan yang dipilih secara acak, kemudian membentangkan roll meter sepanjang 25 meter di kawasan karang guna mengukur persentase tutupan karang dan pengamatan terumbu karang sendiri dilakukan dengan cara snorkeling. Pertumbuhan terumbu karang yang terletak di bawah garis transek diamati dengan cara snorkeling dan mengukur tutupannya dengan menggunakan meteran (English et al., 1994).

\section{Identifikasi Bintang Laut}

Metode yang digunakan untuk mengidentifikasi bintang laut yaitu dengan cara mengambil atau memotret spesies bintang laut dengan kamera underwater, lalu disamakan dengan gambar identifikasi yang sudah disediakan. Gambar yang digunakan untuk mengidentifikasi yaitu dari website berupa database WoRMS (World Register of Marine Species). 


\section{HASIL DAN PEMBAHASAN}

\section{Hasil}

\section{Deskriptif Lokasi}

Pulau Menjangan Kecil berada di Laut Jawa tepatnya di Kecamatan Karimunjawa, Kabupaten Jepara, Provinsi Jawa Tengah. Pulau ini memiliki luas 43, 025 Ha. Posisi geografis dari pulau ini yaitu 05 53'10" - 05 53'50" Lintang Selatan dan $110^{\circ} 26^{\prime} 55^{\prime}$ - $110^{\circ} 29^{\prime} 36^{\prime \prime}$ Bujur Timiur. Pulau ini tidak berpenduduk tetapi memiliki resort untuk menginap para wisatawan.

Penelitian yang dilakukan ini terletak pada sisi Barat dan Timur. Stasiun A terletak pada sisi timur atau sisi yang bersebelahan dengan Pulau Menjangan Besar, sedangkan pada stasiun B terletak pada sisi Barat atau sisi yang menuju laut lepas. Pada koordinat penelitian tersebut gambaran lokasi penelitian yaitu berupa kawasan terumbu karang, pecahan karang dan pasir. Dari ketiga kawasan ini, memiliki kedalaman yang bervariasi. Adapun koordinat dari lokasi penelitian yaitu sebagai berikut.
Stasiun A: $\quad$ Titik A1 : 553'30.01” LS - 110²4'51.70” BT
Titik A2 : 5'53'50.91' LS - 110²4'45.50”'BT
Stasiun B:
Titik B1 : 5053'16.79” LS - 110²4'26.42” BT
Titik B2 : 553'37.88” LS - 110²4’4.88” BT

\section{Pengukuran Parameter Fisika Kimia}

Pengukuran parameter fisiska-kimia di Pulau Menjangan Kecil pada bulan November 2016 dan Mei 2017 tersaji dalam tabel berikut.

Tabel 1. Pengukuran parameter fisika - kimia pada Stasiun A

\begin{tabular}{llccccc}
\hline No. & $\begin{array}{c}\text { Parameter fisika- } \\
\text { kimia }\end{array}$ & Satuan & $\begin{array}{c}\text { Titik 1 } \\
\text { November } \\
\mathbf{2 0 1 6}\end{array}$ & $\begin{array}{c}\text { Mei } \\
\mathbf{2 0 1 7}\end{array}$ & $\begin{array}{c}\text { Titik 2 } \\
\text { November } \\
\mathbf{2 0 1 6}\end{array}$ & $\begin{array}{c}\text { Mei } \\
\mathbf{2 0 1 7}\end{array}$ \\
\hline 1 & Suhu & ${ }^{\circ} \mathrm{C}$ & 27 & 30 & 28 & 30 \\
2 & Kedalaman & $\mathrm{Cm}$ & 187 & 120 & 206 & 140 \\
3 & Kecerahan & $\mathrm{Cm}$ & $\sim$ & 7 & 7 & 7 \\
4 & pH & - & 34 & 34 & 34 & 34 \\
5 & Salinitas & $\%$ oo & & & & 7 \\
\hline
\end{tabular}

Tabel 2. Pengukuran parameter fisika - kimia pada Stasiun B

\begin{tabular}{llccccc}
\hline No. & $\begin{array}{c}\text { Parameter fisika- } \\
\text { kimia }\end{array}$ & Satuan & $\begin{array}{c}\text { Titik 1 } \\
\text { November } \\
\mathbf{2 0 1 6}\end{array}$ & $\begin{array}{c}\text { Mei } \\
\mathbf{2 0 1 7}\end{array}$ & $\begin{array}{c}\text { Titik 2 } \\
\text { November }\end{array}$ & $\begin{array}{c}\text { Me16 } \\
\mathbf{2 0 1 7}\end{array}$ \\
\hline 1 & Suhu & ${ }^{\circ} \mathrm{C}$ & 28 & 30 & 28 & 30 \\
2 & Kedalaman & $\mathrm{Cm}$ & 206 & 121 & 439 & 137 \\
3 & Kecerahan & $\mathrm{Cm}$ & $\sim$ & $\sim$ & $\sim$ & 7 \\
4 & pH & - & 7 & 7 & 34 & 34 \\
5 & Salinitas & $\%$ oo & 34 & & & \\
\hline
\end{tabular}

Dari hasil sampling pada bulan November 2016 dan Mei 2017 di Pulau Menjangan Kecil, Karimujawa ditunjukan pada Tabel 1 dan Tabel 2 yaitu perbandingan nilai data yang tidak jauh berbeda terutama pada suhu perairan. Kisaran suhu yang didapatkan yaitu $27^{\circ} \mathrm{C}-30^{\circ} \mathrm{C}$. Untuk nilai $\mathrm{pH}$ dan salinitas cenderung sama dan tidak jauh berbeda karena kisaran $\mathrm{pH}$ dan salinitas perairan laut yaitu 7 dan $30 \%-36 \%$.

\section{Persentase Tutupan Terumbu Karang}

Persentase tutupan terumbu karang pada penelitian ini disajikan dalam bentuk sebagai berikut.

Tabel 3. Persentase tutupan terumbu karang

\begin{tabular}{clcccc}
\hline No. & \multicolumn{1}{c}{ Kategori } & Titik 1 & Titik 2 & Titik 1 & Titik 2 \\
\hline 1 & & $36 \%$ & $12 \%$ & $36 \%$ & $44 \%$ \\
2 & Karang Hidup (KH) & $8 \%$ & $16 \%$ & $4 \%$ & $12 \%$ \\
3 & Pecahan Karang (PK) & $24 \%$ & $36 \%$ & $12 \%$ & $32 \%$ \\
4 & Pasir (P) & $32 \%$ & $36 \%$ & $48 \%$ & $4 \%$ \\
\hline Total & & $100 \%$ & $100 \%$ & $100 \%$ & $100 \%$ \\
\hline
\end{tabular}


Hasil persentase terumbu karang di perairan Pulau Menjangan Kecil, Karimunjawa yaitu menunjukkan masih dalam kondisi yang sedang atau cukup baik. Pada Tabel 3 diatas juga terdapat persentase pecahan karang yang cukup banyak, hal ini dikarenakan pada beberapa lokasi perairan Pulau Menjangan kecil, Karimunjawa dijadikan sebagai tempat pariwisata seperti snorcling dan jangkar kapal nelayan yang diturunkan dengan cara melemparkan dengan sengaja dan akhirnya merusak karang.

\section{Sebaran Bintang Laut}

Sebaran bintang laut di Pulau Menjangan Kecil tidak melimpah seperti bulu babi dan ikan-ikan karang. Data sebaran bintang laut yang ditemukan tersebut dapat dilihat padaTabel 4 dan gambar grafik dibawah ini.

Tabel 4. Jumlah bintang laut yang ditemukan

\begin{tabular}{|c|c|c|c|c|c|}
\hline \multirow[t]{3}{*}{ No. } & \multirow[t]{3}{*}{ Spesies } & \multicolumn{2}{|c|}{ Stasiun A } & \multicolumn{2}{|c|}{ Stasiun B } \\
\hline & & November & Mei & November & Mei \\
\hline & & 2016 & 2017 & 2016 & 2017 \\
\hline 1 & Linckia laevigata & - & 8 & 14 & 7 \\
\hline 2 & Nordoa tuberculata & 1 & 1 & - & - \\
\hline 3 & Culcita novaeguinae & - & 5 & - & 7 \\
\hline
\end{tabular}

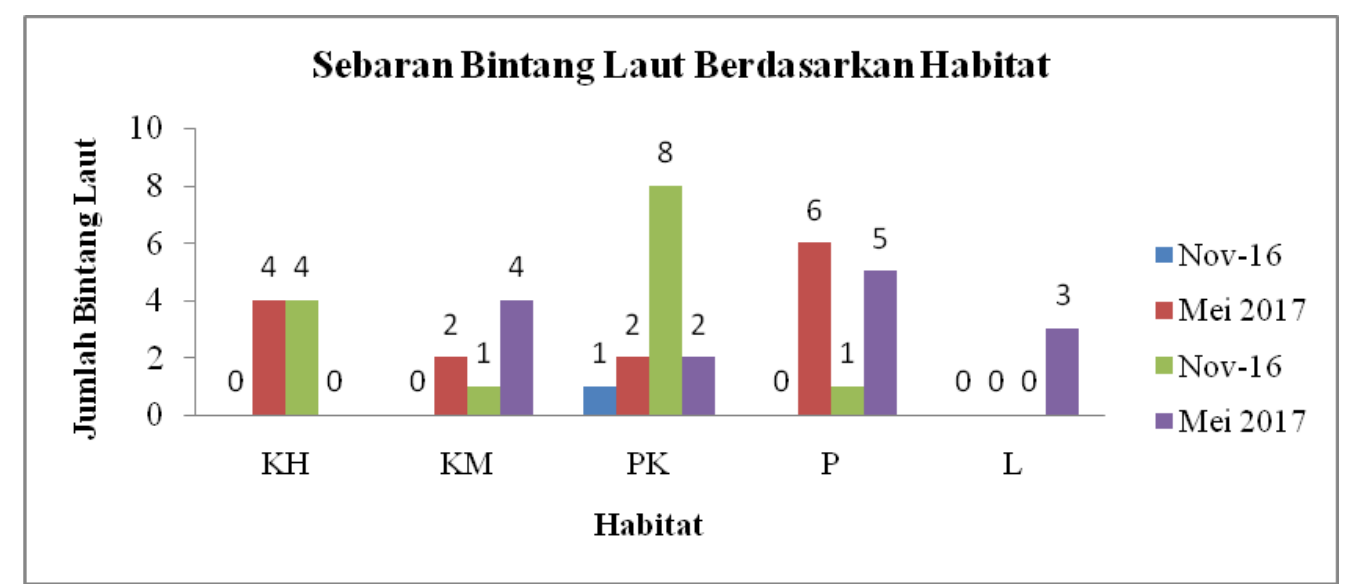

Gambar 1. Grafik sebaran bintang laut berdasarkan habitat

\section{Letak Kedalaman Bintang Laut}

Letak sebaran bintang laut dipengaruhi oleh kedalaman, Penelitian ini dilakukan pada bulan November 2016 dan Mei 2017. Perbandingan data tersebut dapat dilihat pada gambar grafik dibawah ini.

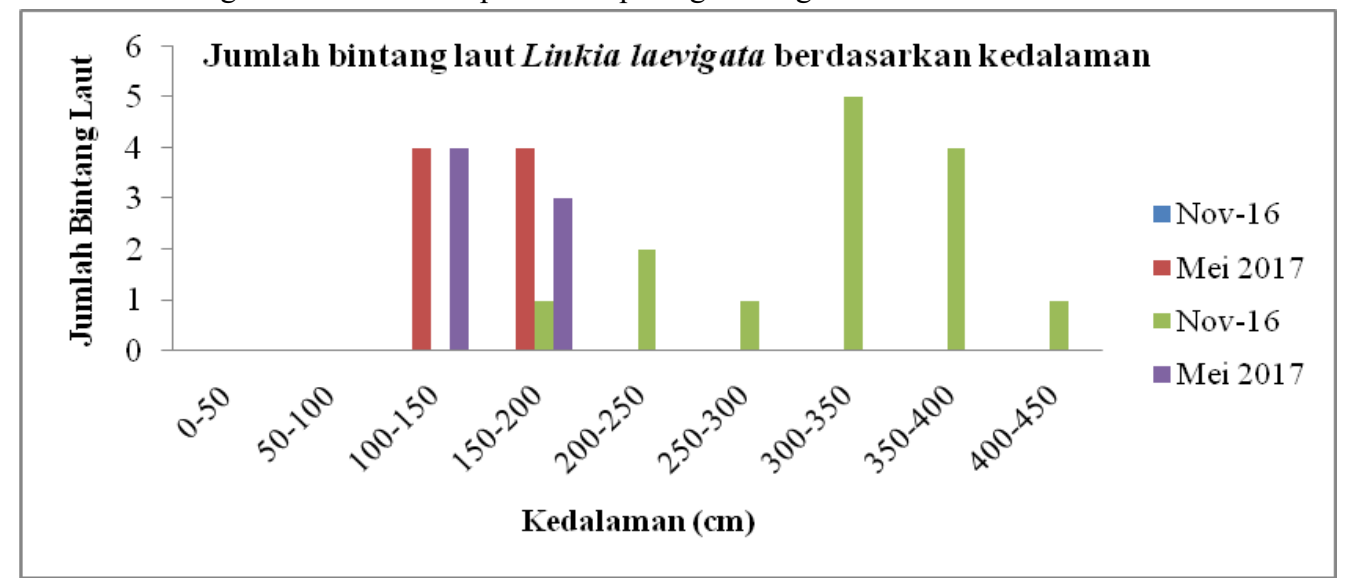

Gambar 2. Jumlah bintang laut Linckia laevigata berdasarkan kedalaman 


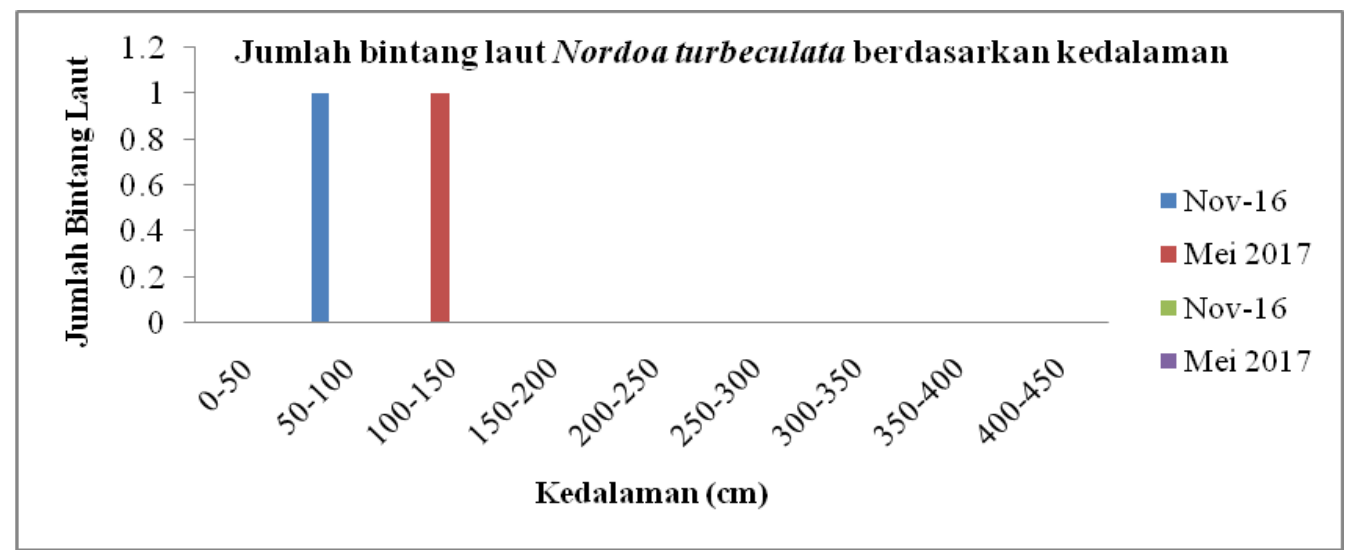

Gambar 3. Jumlah bintang laut Nordoa tuberculata berdasarkan kedalaman

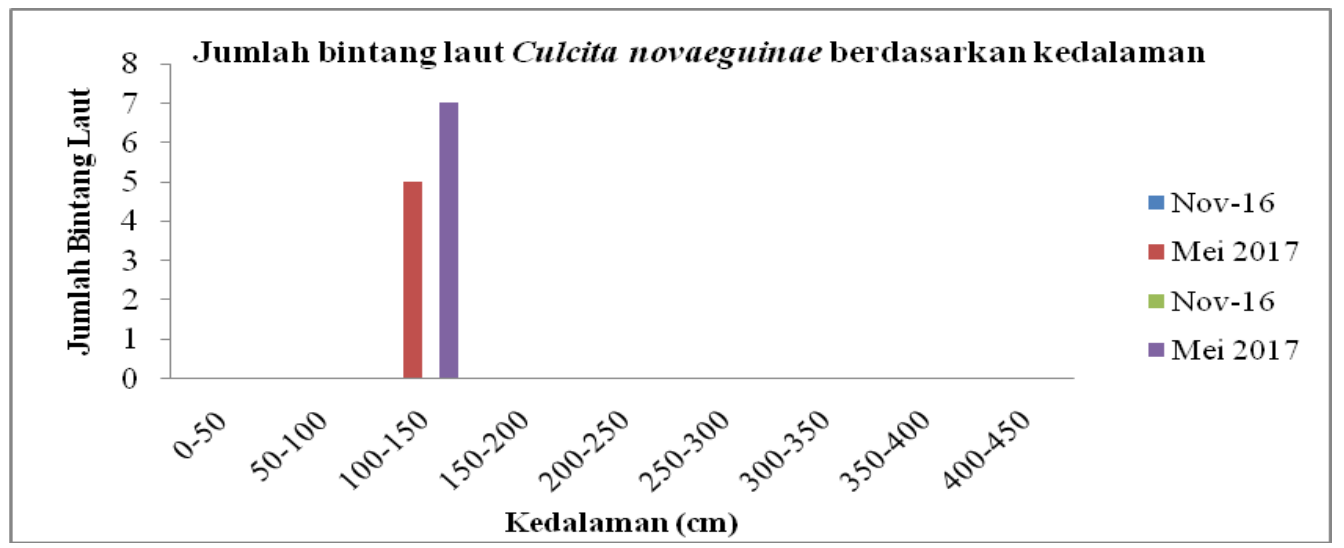

Gambar 4. Jumlah bintang laut Culcita novaeguinae berdasarkan kedalaman

\section{Diameter Bintang Laut}

Bintang laut yang ditemukan di Pulau Menjangan Kecil, Karimunjawa memiliki ukuran diameter yang berbedabeda. Penelitian ini dilakukan pada bulan November 2016 dan Mei 2017. Data tersebut dapat dilihat pada Tabel 5, Tabel 6 dan Tabel 7 dibawah ini.

Tabel 5. Diameter bintang laut spesies Linckia laevigata

\begin{tabular}{|c|c|c|c|c|c|}
\hline \multirow[t]{2}{*}{ No. } & \multirow{2}{*}{$\begin{array}{c}\text { Kategori } \\
\text { Diameter }(\mathrm{cm})\end{array}$} & \multicolumn{2}{|c|}{ Stasiun A } & \multicolumn{2}{|c|}{ Stasiun B } \\
\hline & & $\begin{array}{c}\text { November } \\
2016\end{array}$ & $\begin{array}{c}\text { Mei } \\
2017\end{array}$ & $\begin{array}{c}\text { November } \\
2016 \\
\end{array}$ & $\begin{array}{r}\text { Mei } \\
2017 \\
\end{array}$ \\
\hline 1 & $0-5$ & - & - & - & - \\
\hline 2 & $5-10$ & - & - & - & - \\
\hline 3 & $10-15$ & - & - & - & - \\
\hline 4 & $15-20$ & - & - & - & - \\
\hline 5 & $20-25$ & - & - & 12 & 7 \\
\hline 6 & $25-30$ & - & 8 & 2 & - \\
\hline \multirow{3}{*}{$\frac{1 \text { abel }}{\text { No. }}$} & ter bintang laut & doa tubercu & & & \\
\hline & Kategori & \multicolumn{2}{|c|}{ Stasiun A } & \multicolumn{2}{|c|}{ Stasiun B } \\
\hline & Diameter (cm) & $\begin{array}{c}\text { November } \\
2016\end{array}$ & $\begin{array}{r}\text { Mei } \\
2017\end{array}$ & $\begin{array}{c}\text { November } \\
2016\end{array}$ & $\begin{array}{r}\text { Mei } \\
2017\end{array}$ \\
\hline 1 & $0-5$ & - & - & - & - \\
\hline 2 & $5-10$ & - & - & - & - \\
\hline 3 & $10-15$ & 1 & - & - & - \\
\hline 4 & $15-20$ & - & 1 & - & - \\
\hline
\end{tabular}


Tabel 7. Diameter bintang laut spesies Culcita novaeguinae

\begin{tabular}{|c|c|c|c|c|c|}
\hline \multirow[t]{2}{*}{ No. } & \multirow{2}{*}{$\begin{array}{c}\text { Kategori } \\
\text { Diameter }(\mathbf{c m})\end{array}$} & \multicolumn{2}{|c|}{ Stasiun A } & \multicolumn{2}{|c|}{ Stasiun B } \\
\hline & & $\begin{array}{c}\text { November } \\
2016\end{array}$ & $\begin{array}{l}\text { Mei } \\
2017\end{array}$ & $\begin{array}{c}\text { November } \\
2016\end{array}$ & $\begin{array}{l}\text { Mei } \\
2017\end{array}$ \\
\hline 1 & $0-5$ & - & & - & - \\
\hline 2 & $5-10$ & - & - & - & - \\
\hline 3 & $10-15$ & - & - & - & - \\
\hline 4 & $15-20$ & - & - & - & - \\
\hline 5 & $20-25$ & - & 5 & - & 7 \\
\hline
\end{tabular}

Pembahasan

\section{Pengukuran Parameter Fisika Kimia}

Berdasarkan pengukuran parameter fisika - kimia di perairan Pulau Menjangan Kecil, Karimunjawa pada bulan November 2016 dan Mei 2017 memiliki persamaan pada suhu perairan, yaitu berkisar $27^{\circ} \mathrm{C}-30^{\circ} \mathrm{C}$. Suhu perairan ini masih dalam kategori suhu normal perairan tropis termasuk perairan laut. Hal ini diperkuat oleh Nybakken (1992), suhu perairan lepas pantai di daerah tropis memiliki suhu berkisar $27^{\circ} \mathrm{C}-30^{\circ} \mathrm{C}$, sedangkan diperairan pada waktu tertentu suhu dapat mencapai $36^{\circ} \mathrm{C}-40^{\circ} \mathrm{C}$.

Berdasarkan pengukuran parameter fisika - kimia di perairan Pulau Menjangan Kecil, Karimunjawa pada bulan November 2016 dan Mei 2017 memiliki perbedaan pada kedalaman perairan. Pada bulan November 2016, data kedalaman diperoleh dengan nilai kedalaman $187 \mathrm{~cm}$ dititik 1 dan $206 \mathrm{~cm}$ dititik 2 pada Stasiun A, pada Stasiun B diperoleh nilai kedalamannya $206 \mathrm{~cm}$ dititik 1 dan $439 \mathrm{~cm}$ dititik 2. Sedangkan nilai pengukuran parameter fisika kimia pada bulan Mei 2017 hasil yang yg didapatkan yaitu $120 \mathrm{~cm}$ dititik 1 dan $140 \mathrm{~cm}$ di titik 2 pada Stasiun A, pada Stasiun B nilai kedalaman yang diperoleh yaitu $121 \mathrm{~cm}$ dititik 1 dan $137 \mathrm{~cm}$ dititik 2 .

Hal ini dikarenakan pada bulan November 2016, kondisi cuaca memasuki musim hujan dan dimana kondisi ini menunjukkan perairan sedang pasang. Berbeda dengan bulan Mei 2017, pada bulan ini kondisi cuaca yitu kemarau dan keadaan perairan sedang surut. Hal ini diperkuat oleh Gaffar et al., (2014), bahwa hujan menyebabkan turbulensi perairan lebih tinggi, sehingga perairan menjadi keruh dan diduga akan mempersulit pencarian secara lebih teliti. Pada saat hujan kemungkinan adanya ditemukan bintang laut juga hanya dalam jumlah yang lebih sedikit.

\section{Persentase Tutupan Terumbu Karang}

Berdasarkan penelitian yang dilakukan pada bulan November 2016 dan mei 2017 dan hasil pengukuran tutupan karang ini diukur dari dua sisi yaitu sisi Barat dan sisi Timur Pulau Menjangan Kecil, Karimunjawa. Hasil persentase tutupan terumbu karang yang diperoleh yaitu memiliki kategori baik. Hal ini diperkuat oleh Munasik (2009), terumbu karang di Kepulauan Karimunjawa, baik di dalam kawasan Taman Nasional Karimunjawa maupun di luar kawasan mempunyai kondisi yang bervariasi dari sedang hidngga baik. Kondisi terumbu karang yang baik terdapat, seperti Pulau Menjangan Besar, Pulau Menjangan Kecil, dan di Ujung Gelam Pulau Karimunjawa. Sebaliknya kondisi sedang terdapat di Pulau Burung. Terumbu karang di perairan Pulau Karimunjawa juga memiliki perbedaan kondisi, perbedaan ini diduga akibat perbedaan intensitas kegiatan manusia. Beberapa lokasi terumbu karang dengan kondisi yang buruk diakibatkan karena aktifitas manusia, sebaliknya kondisi terumbu karang yang masih baik cenderung jarang ada aktifitas manusia.

Namun, dibeberapa lokasi penelitian juga ditemukan cukup banyak pecahan karang. Hal ini dikarenakan pada beberapa lokasi tersebut dijadikan tempat atau spot wisata seperti snorcling, banyak dari para wisatawan yang tidak bisa berenang dan kemudian wisatawan tersebut akhirnya menginjak-injak karang. hal ini sangat disayangkan sekali, karena beberapa jenis karang membutuhkan waktu yang sangat lama untuk tumbuh. Hal ini diperkuat oleh Dahuri (2000), penyebab kerusakan terumbu karang dapat dibagi jadi dua, yaitu akibat kegiatan manusia dan pengaruh alam. Kerusakan karang yang paling bersar terjadi diakibatkan oleh kegiatan manusia.

\section{Sebaran Bintang Laut}

Berdasarkan dari data perolehan bintang laut di perairan Pulau Menjangan Kecil, Karimunjawa jumlah bintang laut yang didapatkan pada bulan November 2016 dan Mei 2017 sangat berbeda. Perbedaan perolehan bintang laut pada bulan November 2016 dan Mei 2017 tersebut dipengaruhi oleh cuaca, karena saat dilakukan penelitian pada bulan November 2016 kondisi cuaca sedang mendung dan gerimis kecil. Menurut Gaffar et al., (2014), bahwa hujan menyebabkan turbulensi perairan lebih tinggi, sehingga perairan menjadi keruh dan diduga akan mempersulit pencarian bintang laut maupun biota yang lain secara lebih teliti. Pada saat hujan kemungkinan adanya ditemukan bintang laut juga hanya dalam jumlah yang lebih sedikit.

Menurut Chesher (1969) dalam Moran and Zepp (1997) dalam Gaffar et al., (2014), keberadaan kelimpahan jumlah bintang laut akan berpotensi mudah untuk ditemui ketika cuaca cerah. Karena pada saat itu bintang laut akan 
menyeberangi sand patch untuk mencari makan di perairan dangkal. Bintang laut memiliki preferensi terutama ke areaarea yang lebih terlindung seperti laguna dan perairan yang lebih dalam di sepanjang front reef. Bintang laut spesies Linckia laevigata sebaran populasinya mencakup area terluas jika dibandingkan dengan populasi lain di perairan. Individu-individunya ditemukan di semua tipe habitat, mulai dari intertidal hingga subtidal kedalaman $>10 \mathrm{~m}$. Namun, lebih cenderung tersebar luas dan menempati area mikrohabitat terumbu karang.

Bintang laut spesies Nordoa tuberculata ini sering ditemukan soliter dan selalu menempati area yang tergenang (kedalaman $1.5 \mathrm{~m}-5 \mathrm{~m}$ ). Bintang laut ini pada saat hidup memiliki pola warna tubuh yang sangat mudah dikenali (berwarna belang-belang cokelat tua dan muda) yang melintang di semua lengan, posisinya hanya ditemukan di area terumbu karang seperti celah-celah dan juga berbagai jenis karang, tapi lebih dominan menempati lokasi pecahan karang (rubble), hingga di permukaan pasir sekitar terumbu karang. Nordoa tuberculata merupakan pemakan detritus dan lapisan busukan dari biota sessil bentos (Yusron, 2010).

Bintang laut spesies Culcita novaeguineae memiliki morfologi yang sangat kontras dengan bintang laut lainnya. Bintang laut dengan bentuk tubuh yang gemuk dan lengan yang tidak berkembang ini, ditemukan dominan tersebar pada habitat intertidal. Beberapa individu sering berada dalam kondisi yang terekspos ke udara, namun lebih umum ditemukan berada dalam air laut dengan kedalaman $1 \mathrm{~m}-2 \mathrm{~m}$. Culcita novaeguineae merupakan satu-satunya jenis yang ditemukan lebih dominan di mikrohabitat lamun, namun sebenarnya microhabitat dari bintang laut ini lebih dominan berada di pasir yang berkombinasi dengan lamun. Di mikrohabitat tersebut, Culcita novaeguineae memakan detritus dan juga sedimen organik, hewan kecil yang sessile, hingga polip karang (Lane dan Vandenspiegel, 2003) dalam (Yusron, 2010).

Sebagian besar bintang laut ditemukan di daerah tropis Indo Pasifik. Banyaknya terumbu karang menjadi faktor kelimpahan bintang laut di daerah Indo Pasifik. Seringkali biota ini di ketemukan di dekat terumbu karang atau berasosiasi dengan terumbu karang dan terumbu karang merupakan sumber makanan dari bintang laut. Menurut Lariman (2010) dalam Djibran et al., (2014) salah satu spesies asteroidea ditemukan bersama dan berlimpah pada permukaan yang keras, berbatu, berpasir, atau di dasar yang lunak. Spesies yang lain ditemukan berada di dasar laut yang berbatu. Spesies Asteroidea umumnya soliter tetapi pada kondisi ekologi tertentu bintang laut menghindari sinar matahari langsung atau pengeringan yang berlebihan, beberapa individu berkumpul pada tempat yang sama demi pertahanan. Asteroidea bergerak merayap di atas dasar substrat dengan kecepatan yang agak lambat. Habitat dari bintang laut membentang dari zona intertidal, yaitu pantai yang terkena udara saat air surut dan zona abyssal yang berada di bawah air selama pasang. Tidak hanya di zona intertidal dan zona abyssal, bintang laut sering diketemukan di lubang - lubang kecil. Semua filum Echinodermata memiliki peran dalam ekosistem laut baik ekosistem lamun dan ekosistem terumbu karang. Bintang laut disebut sebagai kunci ekologi yang berperan dalam menjaga keseimbangan ekosistem laut. (Raghunathan dan Venkataraman, 2012 dalam Triana et al., 2015).

\section{Diameter Bintang Laut}

Bintang laut yang diperoleh saat penelitian di perairan Pulau Menjangan Kecil, Karimunjawa pada bulan November 2016 dan Mei 2017 memiliki ukuran diameter yang berbeda-beda, hal ini dipengaruhi oleh kedalaman perairan. Bintang laut spesies Linckia laevigata yang sering ditemukan terutama yang terletak pada substrat pasir cenderung memiliki kisaran diameter $25-30 \mathrm{~cm}$, berbeda dengan yang berada di lokasi karang. Bintang laut spesies Nordoa tuberculata lebih sering ditemukan pada substrat pecahan karang, dan spesies bintang laut yang ditemukan ini memiliki kisaran diameter $10-20 \mathrm{~cm}$. Sedangkan bintang laut spesies Culcita novaeguinae lebih sering ditemukan pada substrat pasir dan lamun, diameter dari bintang laut yang ditemukan ini memiliki kisaran diameter $20-25 \mathrm{~cm}$.

Hal ini dipengaruhi oleh ketersediaan makanannya yang lebih banyak berada pada substrat berpasir seperti endapan serasah detritus. Menurut Aziz (1997), beberapa jenis bintang laut menyukai dasar pasir berlumpur, ini berkaitan dengan kebiasaan makannya sebagai pemakan endapan atau detritus. Selain substrat, faktor abiotik yang mempengaruhi diameter bintang laut adalah $\mathrm{pH}$, jika rata-rata $\mathrm{pH}$ suatu perairan hanya 6,5 hal tersebut dapat mempengaruhi pertumbuhan dari bintang laut. Berbeda dengan rata-rata $\mathrm{pH}$ yang memiliki $\mathrm{pH} 7-7,5$ yang termasuk dalam kondisi kisaran normal untuk kehidupan bintang laut.

Suhu perairan juga mempengaruhi proses pemijahan bintang laut, karena suhu mempengaruhi aktifitas metabolisme bintang laut. Suhu yang masih dalam batas toleran untuk kehidupan bintang laut yaitu berkisar antara $25^{\circ} \mathrm{C}$ sampai dengan $30^{\circ} \mathrm{C}$ (Aziz, 1998).

Tidak hanya itu, kisaran salinitas juga berpengaruh terhadap kehidupan bintang laut terutama pada pertumbuhan dan perkembangan dari larva bintang laut. Menurut Aziz (1998), bintang laut adalah penghuni sejati dengan batasan toleransi salinitas $30-34 \%$. Larva bintang laut lebih sensitif terhadap pengaruh penurunan ataupun kenaikan salinitas, berbeda dengan bintang laut dewasa. Bila dibandingkan dengan kelompok biota lainnya, larva fauna Echinodermata lebih sensitif terhadap perubahan salinitas. 


\section{Kondisi Perairan Pulau Menjangan Kecil Saat Malam Hari}

Berdasarkan penelitian yang dilakukan di Pulau Menjangan Kecil saat malam hari yaitu banyak sekali biota laut yang muncul menampakkan diri, seperti ikan hiu berjumlah 2 ekor pada sisi barat Pulau Menjangan Kecil. Ular laut berjumlah 1 ekor pada sisi barat Pulau Menjangan Kecil. Banyak ikan buntal pada sisi utara, selatan, barat dan timur Pulau Menjangan Kecil. Kemudian kondisi perairan laut saat malam hari terlihat sangat indah karena zooplankton yang berada di permukaan perairan muncul dengan cahaya berwarna biru.

\section{KESIMPULAN}

Kesimpulan yang dapat diambil dari penelitian ini yaitu persentase kondisi tutupan terumbu karang di perairan Pulau Menjangan Kecil, Karimunjawa yaitu masih dalam kategori cukup baik dengan persentase pada stasiun A dititik 1: karang hidup $36 \%$, karang mati $8 \%$, pecahan karang $24 \%$, dan pasir $32 \%$. Pada stasiun A dititik 2 : karang hidup $12 \%$, karang mati $16 \%$, pecahan karang $36 \%$, dan pasir $36 \%$. Sedangkan persentase tutupan karang pada stasiun B dititik 1: karang hidup 36\%, karang mati $4 \%$, pecahan karang $12 \%$, dan pasir $48 \%$. Pada stasiun B dititik 2: karang hidup 44\%, karang mati $13 \%$, pecahan karang $32 \%$, dan pasir $4 \%$. Letak sebaran bintang laut secara vertikal di Pulau Menjangan Kecil, Karimunjawa yaitu untuk bintang laut spesies Linckia laevigata lebih sering ditemukan pada kedalaman 100 $450 \mathrm{~cm}$. Bintang laut spesies Nordoa tuberculata lebih sering ditemukan pada kedalaman $50-150 \mathrm{~cm}$. sedangkan bintang laut spesies Culcita novaeguinae lebih sering ditemukan pada kedalaman $100-150 \mathrm{~cm}$. Letak sebaran bintang laut secara horizontal di Pulau Menjangan Kecil, Karimunjawa yaitu untuk bintang laut spesies Linckia laevigata lebih sering ditemukan pada lokasi karang hidup, karang mati dan substrat pasir. Bintang laut spesies Nordoa tuberculata lebih sering ditemukan pada lokasi pecahan karang. sedangkan pada bintang laut spesies Culcita novaeguinae lebih sering ditemukan pada lokasi lamun dan substrat berpasir. Hubungan bintang laut dengan kedalaman di perairan Pulau Menjangan Kecil, Karimunjawa yaitu dipengaruhi oleh faktor makanan, karena bintang laut memiliki kebiasaan makan endapan atau serasah detritus pada substrat berpasir. Maka dari itu cukup banyak bintang laut yang ditemukan pada substrat berpasir.

\section{Ucapan Terimakasih}

Ucapan terimakasih ditujukan kepada Tuhan YME yang telah memberikan kelancaran sehingga penulis dapat menyelesaikan tulisan ini. Selanjutnya ucapan terimakasih juga ditujukan kepada penguji Dr. Ir. Suryanti, M. Pi yang telah memberikan kritik dan sarannya guna untuk menyempurnakan artikel ini.

\section{DAFTAR PUSTAKA}

Aziz, A. 1997. Pengamatan Komunitas Echinodermata di Teluk Jakarta. Jurnal Oseanografi dan Limnologi di Indonesia. 30(1): $1-12$.

. 1998. Beberapa Catatan Tentang Daur Hidup Bintang Laut Pemakan Karang. Jurnal Oseana. 23(2): $11-17$.

Ariyati, R. W., S. Lachmuddin, dan A. Endang. 2007. Analisis Kesesuaian Perairan Pulau Karimunjawa dan Pulau Kemujan Sebagai Lahan Budidaya Rumput Laut Menggunakan Sistem Informasi Geografis. Jurnal Pasir Laut. 3(1): $27-45$.

Dahuri, R. 2000. Kebijakan dan Strategi Pengelolaan Terumbu Karang Indonesia. Prosiding Pengelolaan dan IPTEK Terumbu Karang Indonesia: $1-16$.

Djibran, F., J. L. Chairunnisah, dan S. K. Abubakar. 2014. Diversitas Jenis Bintang Laut (Asteroidea) Di Perairan Torosiaje Kecamatan Popoyato, Kabupaten Pohuwato. Fakultas MIPA Universitas Negeri Gorontalo.

English, S., C. Wilkinson, dan V. Baker. 1994. Survey Manual for Tropical Marine Resources. Australian Institute of Marine Science. Townsville. $358 \mathrm{pp}$.

Gaffar, S., P. Z. Neviaty, dan P. Pradina. 2014. Prefensi Mikrohabitat Bntang Laut Perairan Pulau Hari, Sulawesi Tenggara. Jurnal Ilmu dan Teknologi Kelautan Tropis. 6(1): $1-15$.

Katili, A. S. 2011. Struktur Komunitas Echinodermata Pada Zona Intertidal Di Gorontalo. Jurnal Penelitian dan Pendidikan. 8(1): 51 - 61 .

Munasik. 2009. Konservasi Terumbu Karang. Badan Penerbit Universitas Diponegoro. Semarang.

Nybakken, J. W. 1992. Biologi Laut Suatu Pendekatan Ekologis, Jakarta : PT Gramedia Pustaka Utama.

Sugiyono. 2003. Metode Penelitian Bisnis. Bandung. Pusat Bahasa Depdiknas.

Triana, R., E. Dewi, dan B. V. Indra. 2015. Identifikasi Echinodermata di Selatan Pulau Tikus, Gugusan Pulau Pari, Kepulauan Seribu, Jakarta. PROS SEM NAS MASY BIODIV INDON. 1(3): 455 - 459.

Umar, H. 2001. Strategic Management in Action. Gramedia Pustaka Utama. Jakarta.

Yusron, E. 2010. Biodiversitas Ekhinodemata di Perairan Pantai Takofi, Pulau Moti - Maluku Utara. Makara Sains, 14: 79-83. 